\title{
NUBUATAN TENTANG MESIAS DARI KITAB PARA NABI
}

\author{
Ditulis Oleh : Dr. Kuntjoro Tjondro ${ }^{1}$
}

\begin{abstract}
The concept of the Messiah according to the Old Testament prophets originated because of the threat that made the Kingdom of Israel and Judah fell into the hands of the enemy and made them live in misery. The Prophets delivered the news of the coming of a king from David's descendant who was raising the fallen kingdom of David. This Messiah's person is very powerful because there is a Spirit of God that is in him so as to be able to restore, rule the kingdom so that the atmosphere of peace, full of abundance and security and justice is felt by the people. Messiah is a liberator who is able to release his people from the threat of foreign nation. The concept of the Messiah as a political liberator and power ultimately held by the Israelites to the present day.
\end{abstract}

\begin{abstract}
Abstrak
Konsep Mesias menurut para nabi Perjanjian Lama bermula karena ancaman yang menjadikan Kerajaan Israel dan Yehuda jatuh ke tangan musuh dan menjadikan mereka hidup dalam penderitaan. Para Nabi menyampaikan berita tentang kedatangan seorang raja dari keturunan Daud yang kan memumulihkan kerajaan Daud yang telah runtuh. Pribadi Mesias ini sangat perkasa karena ada Roh Allah yang ada padaNya sehingga mampu untuk memulihkan, memerintah kerajaan sehingga suasana damai sejahtera, penuh dengan kelimpahan dan keamanan serta keadilan dirasakan oleh masyarakat. Mesias adalah seorang pembebas yang mampu melepaskan bangsanya dari ancaman bangsa asing. Konsep Mesias sebagai pembebas secara politik dan kekuasaan yang akhirnya dipegang oleh bangsa Israel hingga masa kini.

Satu kata yang mewakili bahasa Ibrani (mashiah), bahasa Aram (meshiha), dan bahasa Yunani (Messias) Arti dasar dari Mesias ini adalah "orang yang diurapi."2 Gelar Mesias ini dipakai untuk penyelamatan yang akan datang, dan bahkan orang Yahudi percaya bahwa yang akan menyelamatkan pada masa yang akan datang adalah Allah sendiri. Walaupun ungkapan Mesias ini tidak digunakan secara langsung, namun ada bermacam-macam dalam penggunaannya dalam rangkaian kata seperti Masias Tuhan (artinya yang diurapi Tuhan). Gagasan mengenai pengurapan seseorang untuk suatu tugas khusus, muncul beberapa kali, terutama bagi-raja-raja dan imam-imam (Im. 4:3 dan selanjutnya); juga bagi nabi-nabi (1 Raj. 19:16); dan bapak-bapak leluhur Israel (Mzm. 105:15). Pengurapan ini digunakan dalam tugas khusus dan kemudian digunakan dalam hal yang lebih teknis, hkususnya bagi seseorang yang

\footnotetext{
${ }^{1}$ Penulis adalah Dosen pada Program Studi Pasca Sarjana di Sekolah Tinggi Teologia Nazarene Indonesia.

2 J. D. Douglas \& Merrill C. Tenney, The New International Dictionary Of The Bible (Michigan: Zondevan Publishing House, 1987), 644.
} 
akan dipilih Allah sebagai alatNya untuk menyelamatkan umatNya. ${ }^{3}$ George E. Ladd mengungkapkan bahwa pengurapan itu berkaitan dengan penugasan ilahi untuk jabatan teokrasi tertentu dan dengan demikian menunjukan bahwa oleh pengurapan itu mereka digolongkan dengan kelompok hamba Allah yang khusus dan pribadi mereka suci (1 Taw. 16:22), dan kesuciannya tersebut berkaitan dengan jabatannya. ${ }^{4}$

Dalam Perjanjian Lama pengurapan itu dengan minyak yang melambangkan Roh Tuhan (Yes. 61:1; Za. 4:1-6), dan pengurapan itu melambangkan peralihan Roh Tuhan pada orang yang dipilihnya (1 Sam. 10:1, 6, 10: 16:13, 14). Pengurapan itu adalah tanda yang nampak bagi pemilihan atas seseorang untuk menduduki jabatan tertentu; untuk peneguhan sesuatu hubungan sakral dan suasana sakral yang ditimbulkan dari diri orang yang diurapi (1 Sam. 24:6; 26:9; 2 Sam 1:14). Pengurapan juga berkaitan dengan pencurahan Roh Allah kepada orang yang diurapi (1 Sam 1:13, bandingkan 1 Kor. 1:21-22). ${ }^{5}$

Jikalau pengertian Mesias tersebut dikaitkan dengan seorang raja yang sedang berkuasa di kerajaan Israel, terutama berasal dari dinasti Daud, namun pengertiannya menjadi berkembang, seperti yang dikutip oleh Siahaan dari Gressman ini:

Mesias itu hanya ada satu, yang di dalam dirinya membawa keselamatan pada bangsa Israel dan seluruh umat manusia. Dalam perjalanan waktu, pengharapan ini semakin kabur. Dalam situasi ini, masuklah pemkiran-pemikiran eskatologis yang dapat berakibat pindahnya pengharapan mesianis ke waktu dekat, atau pun waktu yang jauh dari para pendengar nubuat. ${ }^{6}$

Dari gagasan-gagasan tentang Mesias seperti yang terungkap di atas terlihat bahwa ada campur tangan Allah dalam menentukan tokoh tertentu, entah itu seorang raja, imam, dan nabi. Pengurapan yang diberikan menyebabkan pribadi tersebut memiliki kuasa ilahi sehingga dapat menjalankan tugasnya dengan baik. Keterlibatan Allah dalam menjalankan tugasnya menjadikan pribadi tersebut berhasil.

Untuk mendapatkan gambaran tentang Mesias secara tuntas, penelitian Alkitab ini akan dimulai dari Perjanjian Lama, kemudian diteruskan dalam Perjanjian Baru. Penelitian Alkitab ini hanya dibatasi dengan konsep tentang Mesias, baik itu dalam nubuatan ataupun keterangan yang lain yang menunjang.

\section{Latar Belakang Pemikiran}

Pemikiran tentang datangnya Mesias sering dikaitkan dengan penderitaan yang sangat berat dan berkepanjangan yang dialami oleh bangsa Yahudi Israel. Mereka mengharapkan seorang pembebas yang mampu untuk membebaskan mereka dari kekuasaan bangsa asing. Pembebas tersebut akan memimpin mereka dan memberikan kesejahteraan, kedamaian, serta hidup dalam kelimpahan. Mereka mengingat janji Allah kepada nenek moyang mereka ketika

\footnotetext{
${ }^{3}$ Donald Guthrie, Teologi Perjanjian Baru 1 (Jakarta: BPK Gunung Mulia, 2011), 261.

${ }^{4}$ George Eldon Ladd, Teologi Perjanjian Baru 1, (Bandung: Yayasan kalam Hidup, 2002), 178.

${ }^{5}$ Louis Berkhof, Teologi Sistematik 3, Doktrin Kristus, terjemahan:Yudha Thianto, (Surabaya: Penerbit Momentum, 2008), 24-25.

${ }^{6}$ M.S. Siahaan, Pengaharaan Mesias dalam Perjanjian Lama, (BPK: Gunung Mulia, 1990), 5.
} 
keluar dari Mesir dan menempati tempat yang berkelimpahan air susu dan madu. Mereka mengidam-idamkan suasana keselamatan secara utuh dan bulat lengkap yang akan diwujudkan di bawah kekuasaan Mesias sebagai Raja. Dalam kekuasaan Mesias, selain menikmati kelimpahan secara materi juga menikmati hubungan kemesraan dengan Yahwe. ${ }^{7}$

Ketika bangsa Israel dan Yehuda hidup dalam dosa, maka Allah menghukum mereka dengan menggunakan bangsa-bangsa lain untuk menindas dan menjarah harta benda mereka sehingga Israel mengalami penderitaan. Nabi-nabi Tuhan telah mengingatkan mereka untuk bertobat dan kembali kepada Tuhan dan janji Tuhan tentang peemulihan diberikan jika mereka betul-betul bertobat. Janji pemulihan ini berkaitan dengan Mesias yang diutus oleh Tuhan untuk membebaskan mereka. ${ }^{8}$ Itulah inti berita Firman yang disampaikan para nabi bagi orang Israel.

Pokok penting yang mendasari para nabi Tuhan bernubuat tentang Mesias adalah nubuatan yang terdapat dalam Kejadian 49:10, dan 2 Samuel 7:10-15, yang sering disebut sebagai Perjanjian Allah dengan Daud.

Tongkat kerajaan tidak akan beranjak dari Yehuda ataupun lamang pemerintahan dari antara kakinya, sampai dia datang yang berhak atasnya, maka kepadanya akan takluk bangsabangsa (Kej. 49:10).

Aku menentukan tempat bagi umatKu Israel dan menanamkannya, sehingga ia dapat diam di tempatnya sendiri dengan tidak lagi dikejutkan dan tidak pula ditindas oleh orang lalim seperti dahulu, sejak Aku mengangkat hakim-hakim atas umatKu Israel. Aku mengaruniakan keamanan kepadamu dari pada semua musuhmmu. Juga diberitahukan TUHAN kepadamu: TUHAN akan memberikan keturunan kepadamu. Apabila umurmu sudah genap dan engkau telah mendapat perhentian bersama-sama dengan nenek moyangmu, maka Aku akan membangkitkan keturunanmu dan kemudian, anak kandungmu, dan Aku akan mengkokohkan kerajaannya. Dia yang akan mendirikan rumah bagi namaKu dan Aku akan mengkokohkan takhta kerajaannya untuk selama-lamanya. Aku aakan menjadi Bapanya dan ia akan menjadi anakKu. Apabila ia akan melakukan kesalahan, maka aku akan menghukum dia dengan rotan yang dipakai orang dan dengan pukulan yang diberikanaanak-anak manusia. Tetapi kasih setiaKu tidak akan hilang dari padanya, seperti yang kuhilangkan dari pada Saul, yang telah kujauhkan dari hadapanmu. Keluarga dan kerajaanmu akan kokoh untuk selama-lamanya dihadapanKu, takhtamu akan kokoh untuk selama-lamanya (2 Sam. 7:10-15).

Hal-hal inilah yang melatar belakangi konsep Mesias yang disampaikan oleh para nabi. Dari nubuatan tersebut, bangsa Israel selalu menanti kedatangan Mesias sebagai pembebas, manakala mereka sedang menghadapi penindasan dan kesengsaraan.

${ }^{7}$ C. Groenen, Pengantar ke Dalam Perjanjian Lama (Yogyakarta: Kanisius, 1992), 87-88.

${ }^{8}$ Willem A. VanGemeren, Penginterpretasian Kitab Para Nabi (Surabaya: Momentum, 2011), 22. 


\section{Berita Mesias Dari Para Nabi}

\section{Nabi Yesaya}

Nubuatan Yesaya tentang Mesias tertuang dalam pasal 7:10-17, tentang kelahiran Imanuel, pasal 9:1-6, tentang kelahiran Raja Damai, dan pasal 11:1-5, tentang Tunas Adil yang keluar dari tunggul Isai.

Yesaya 7:10-17, didahului dengan pertemuan nabi Yesaya dengan raja Ahas (Yes. 9:17), di mana raja mengalami ketakutan karena ancaman dari Aram dan Efraim. Nabi Yesaya menasehatkan agar raja tetap teguh hati, tinggal tenang, dan tidak takut serta kecut hati (ay. 4). Yesaya melanjutkan nasehatnya agar raja meminta tanda dari Tuhan, namun raja Ahas tidak mau karena hal tersebut mencobai Tuhan (ay.10-12). Karena Ahas tidak mau meminta tanda, maka Tuhan sendiri yang memberikan tanda, dan muncul ayat 14-17, tentang kelahiran anak laki-laki dari seorang perempuan muda, dan dinamakan Imanuel.

Nubuat tentang Imanuel muncul karena ketakutan raja Ahas yang kerajaannya sedang goyah. Anak laki-laki yang lahir dari perempuan muda/perawan tersebut sudah dekat kelahirannya, dan ia akan membuka babak sejarah baru bagi kerajaan Ahas. ${ }^{9}$ Memang Imanuel ini multi tafsir, namun menurut para ahli Imanuel adalah suatu rahasia, dan Imanuel adalah Mesias, ${ }^{10}$ Allah beserta kita. ${ }^{11}$ Nama Imanuel dapat diartikan bahwa Allah bersama dengan bangsa Israel. Nubuatan Imanuel ini merupakan berita dan pesan yang sentral bagi bangsa Israel yang tidak setia pada waktu itu. ${ }^{12}$

Yesaya 9:5-6, mengungkapkan gagasan tentang kelahiran anak yang lambang pemerintahan ada di atas bahunya, namanya disebut: Penasehat Ajaib, Allah yang Perkasa, Bapa yang Kekal, Raja Damai. Juga mengungkapkan tentang kekuasaan dari takhta Daud yang kokoh dengan damai sejahtera yang tidak berkesudahan, serta keadilan dan kebenaran selama-lamanya. Apa yang dinubuatkan Yesaya ini menunjuk pada kerajaan Mesias yang akan datang yang akan terjadi.

Suatu pujian umumnya ditujukan bagi kemuliaan Allah karena perbuatan-perbuatanNya yang besar bagi umat pilihanNya dalam menghadapi ketertindasan yang berat oleh kekuasaan asing (9:1-4). Pujian kepada Allah juga diberikan karena pemberian Allah seorang raja yang adil, yang memberikan damai sejahtera kepada bangsa pilihan Allah ini. "Seorang putera telaah diberikan untuk kita" (ay. 5), ini berarti bahwa semuanya belum menjadi kenyataan, namun saatnya itu sudah pasti dan tinggal menunggu putusan Allah, sehingga umatNya sudah dapat memuliakannya (ay. 6). ${ }^{13}$

Nubuatan yang penuh dengan pengharapan dan sukacita ini diberi tempat di tengahtengah konteks yang hampir seluruhnya suram dan bahkan gelap. Bangsa Israel sudah menunggu pembawa keselamatan bagi mereka yang pribadinya mempunyai predikat manusia ilahi. Dengan mengacu pada proses kelahiran, maka Yesaya menunjuk hubungan nubuat tersebut dengan

\footnotetext{
${ }^{9}$ S.H. Widyapranawa, Tafsiran Alkitab, Kitab Yesaya (Jakarta: BPK Gunung Mulia, tt), 44.

${ }^{10}$ M.S. Siahaan, Pengaharaan Mesias. 17.

${ }^{11}$ S.H. Widyapranawa, Tafsiran Alkitab. 42.

${ }^{12}$ Ibid.

${ }^{13}$ C. Barth, Theologia Perjanjian Lama (Jakarta: BPK Gunung Mulia, 1989), 158.
} 
nubuat pada Yesaya 7:14, dasar pemerintahannya adalah keadilan. Predikat-predikat lainnya adalah: Penasehat Ajaib, Allah yang Perkasa, Bapa yang Kekal, dan Raja Damai, dan hal tersebut adalah menunjuk pada kehebatan dari raja yang akan datang. ${ }^{14}$

Yesaya 11:1-9, memberikan gambaran bahwa Mesias adalah keturunan Daud. Ayat ini mengungkapkan tentang Mesias akan datang dengan membawa suasana yang penuh dengan kedamaian. Kekuasaan dari dinasti Daud mengalami kemerosotan, dan hanya tinggal tunggulnya saja yang masih besar. Suasana kelimpahan dan keamanan seperti di masa raja Daud sudah berlalu, dan mereka kehilangan kehidupan yang baik. ${ }^{15}$

Mesias yang dijanjikan tersebut berasal dari tunggul Isai (Yes. 11:1). "Tunggul" menjelaskan tentang pangkal pohon yang masih tinggal sehabis ditebang. Nampaknya harus mengalami penebangan terlebih dahulu keluarga Daud, sebagai keturunan Isai, kemudian baru keluar tunas, yakni raja yang takut akan Tuhan, sebab Roh Tuhan ada padanya ( Yes. 11:2-3). ${ }^{16}$ Raja-raja keturunan Daud yang lama harus mengalami kematian terlebih dahulu sebelum raja yang baru sebagai raja damai itu berkuasa. Pribadi tersebut merupakan makhluk sorgawi dan bukan sekedar manusia biasa, karena Roh Allah ada padanya. ${ }^{17}$ Bagian teks ini menekankan bahwa ia akan memerintah sebagai raja yang memiliki wilayah pemerintahan. Ia sebagai hakim adil yang membela hal orang-orang tertindas, dengan wibawa penuh (Yes. 11:3-4). Raja tersebut dengan kerendahan hati tetap melayani rakyatnya yang membutuhkan, supaya keadilan dan kebenaran dapat diwujudkan dalam pemerintaahannya. ${ }^{18}$ Nubuatan tentang raja dari tunggul Isai itu adalah Mesias yang dinanti-nanti dan muncul di akhir zaman. ${ }^{19}$

Dari ketiga nubutan dalam kitab Yesaya ini berkaitan dengan Mesias sebagai keturunan dari Daud, ia akan berkuasa dan mendirikan serta mengkokohkan kembali takhta Daud yang sudah runtuh. Dalam pemerintahannya, ia akan menjalankan dengan keadilan yang menimbulkan kebenaran dan damai sejahtera. Hal tersebut dapat terjadi karena Roh Allah tinggal padanya yang sangat tegas dengan ungkapan "Imanuel", "Roh Allah ada padanya".

\section{Nabi Yeremia}

Yeremia hidup setelah nabi Yesaya yang lebih dahulu bernubuat tentang Mesias. Nubuat tentang Mesias yang disampaikan nabi Yeremia ada pada pasal 23:5-6.

Sesungguhnya, waktunya akan datang, demikianlah firman TUHAN, bahwa Aku akan menumbuhkan Tunas adil bagi Daud. Ia akan memerintah sebagai raja yang bijaksana dan akan melakukan keadilan dan kebenaran di negeri. Dalam zamannya Yehuda akan dibebaskan, dan israel akan hidup dengan tenteram; dan inilah namanya yang diberikan orang kepadanya: TUHAN keadilan kita.

${ }^{14}$ M.S. Siahaan, Pengaharaan Mesias. 18.

${ }^{15}$ Derek Kidner, Tafsiran Alkitab Masa Kini 2, terj:W.B. Sijabat (Jakarta: BPK Gunung Mulia, 1985),

385.

${ }^{16}$ John F.Walvoord, Roy B. Zuck (ed), The Bible Knoledge Commentary (Colorado: Chariot Victory Publishing), 1056.

${ }^{17}$ Barth. Theologia. 159.

${ }^{18}$ Ibid.

${ }^{19}$ Ibid. 160 . 
Melihat konteks dari nubuat ini menunjukkan betapa kecewanya nabi Yeremia terhadap penguasa-penguasa pada waktu itu. Setelah kematian raja Yosia, tidak ada raja yang melakukan keadilan dan kebenaran (Yer. 22:15-16). Yerusalem jatuh ke tangan Babil, dan raja Zedekia sebagai raja takhlukan menjadi lalim. Saat itulah nabi Yeremia bernubuat tentang "tunas adil" dari keturunan Daud sebagai pengganti pohon keluarga Daud yang bakal ditebang. Tunas yang dimaksud adalah untuk menelusuri garis leluhur Mesias, manusia dan ilahi, dan penggunaannya yang sebenarnya, dan gelar Mesias ini terpusat pada kenyataan imammiah dan keraajaan Mesias. ${ }^{20}$ Pribadi yang dijanjikan dalam nubuat tersebut adalah seorang raja Yehuda, namun seorang raja yang ditunjang sepenuhnya oleh kuasa Tuhan, ${ }^{21}$ dan itu adalah Mesias.

Nubuat tentang "tunas adil" ini memang tidak digenapi dalam waktu yang dekat, ketika Yerusalem menjadi puing-puing, dihancurkan oleh Babil. Nubuat tentang tunas adil ini masih tetap hidup dan dipercaya oleh umat Yahudi dengan menantikan Mesias yang akan berkuasa dan memerintah dengan menjalankan kebenaran dan keadilan. ${ }^{22}$

Nubuat yang lain dari Yeremia ada pada pasal 33:14-18. Pada teks ini diungkapkan juga tentang tunas keadilan, namun disinggung juga tentang keimaman suku Lewi. Hal ini disebabkan keimaman Lewi ini tidak dapat dipisahkan dengan kekuatan Israel. Perpaduan ini diyakini akan menjadi kekuatan yang tangguh akan kebangkitan Israel baru dengan perpaduan antara keagamaan dan bangsa. Kedatangan Mesias akan dapat mewujudkan negeri tersebut. Israel dan Yehuda disebut, menunjuk pada perpecahan negeri tersebut, namun pada masa akan datang Mesias akan menggabungkan kembali kerajaan Israel baru (ay. 14). ${ }^{23}$

Jadi Yeremia memposisikan para imam di samping kerajaan, dan Yerusalem sebagai pusat peribadatan dan pemujaan, di mana kerajaan dan keimaman menjadi tumpuhan bangsa dan negara pada masa akan datang. Ia menginginkan keadilan dan kebenaran akan mewarnai Yerusalem, dan hal ini diwujudkan pada pemerintahan Mesias. Mesias sebagai wakil Allah, Ia berhubungan langsung dengan Allah, Ia dapat mendekati Allah untuk menjelaskan permasalahan bangsanya.

\section{Nabi Yehezkiel}

Bagian kitab Yehezkiel yang mengungkapkan tentang nubuatan Mesias adalah pasalpasal 17:22-24; 34:23-24, dan 37:22-25. Ia tidak mengungkapkan secara langsung dan detail tentang Mesias, tetapi menggunakan simbol-simbol. Simbol-simbol yang berkaitan dengan Mesias ini memang cukup sulit, tetapi jelas bahwa yang dimaksud oleh Yehezkiel adalah Mesias. $^{24}$

Yehezkiel 17:22-24. Pokok-pokok penting yang perlu dimengerti dalam teks nubuatan ini adalah: burung rajawali besar (ay. 3) adalah raja Nebukadnezar; Libanon adalah daerah pegunungan Yehuda; puncak pohon aras adalah dinasti Daud hingga Yoyakhin. Negeri perdagangan (ay. 4) merujuk pada Babel. Tempat dekat air berlimpah-limpah (ay. 5) adalah

\footnotetext{
${ }^{20}$ F. Cawley, A.R. Millard, Tafsiran Alkitab Masa Kini 2 (Jakarta: BPK Gunung Mulia, 1985), 465.

${ }^{21}$ Barth. Theologia. 161.

${ }^{22}$ Ibid. 162.

${ }^{23}$ Cawley, A.R. Millard, Tafsiran Alkitab. 476.

${ }^{24}$ M.S. Siahaan, Pengaharaan Mesias. 46.
} 
Palestina, pohon anggur yang rimbun yang tumbuhnya rendah adalah Nebukadnezar membiarkan Zedekia menduduki takhta dengan membayar upeti (ay. 6), dan burung rajawali besar yang lain adalah Firaun dari Mesir (ay. 7). ${ }^{25}$

Secara latar belakang nubuatan, raja Zedekia mencari pertolongan pada Mesir untuk menghadapi Babel, dan ketidak setiaan Zedekia terhadap sumpahnya kepada Nebukadnezar. ${ }^{26}$ Di samping kecaman, Yehezkiel mengiringi dengan pengharapan yang akan datangnya Mesias dengan menggunakan gambaran "pohon aras". Sebatang pohon aras besar akan tumbuh puncak aras yang tumbuh di Babel, setelah dipindahkan ke Palestina di gunung yang tinggi. Mereka sadar bahwa yang merendahkan pohon yang tinggi dan meninggikan pohon yang rendah, dan membuat pohon yang tumbuh menjadi layu kering adalah TUHAN (ay. 22-24). Jikalau "aras" tersebut adalah dinasti Daud hingga Yoyakhin, maka pucuk yang muda menunjuk pada seorang raja baru yang masih termasuk dinasti Daud yang akan diangkat Tuhan untuk menduduki takhta Daud. Jadi pucuk itu adalah simbol dari seseorang, bukan dinasti baru. Dahan-dahan baru itu dapat diartikan sebagai dinasti keselamatan baru, sehingga akan ada beberapa Mesias (seorang pembebas). Yehezkiel ingin mengungkapkan penderitaan Israel dalam pembuangan disebabkan oleh raja Zedekia yang memberontak Babel. Dengan ide Mesias tidak seorang, maka Zerubabil dianggap sebagai Mesias. ${ }^{27}$

Yehezkiel 34:23-24, membuka janji kedatangan gembala yang baru. Aku akan mengangkat satu orang gembala atas mereka, yang akan menggembalakannya, yaitu Daud, hambaKu; dia akan menggembalakan mereka, dan menjadi gembalanya (ay. 23). Dan Aku TUHAN, akan menjadi Allah mereka serta serta hambaKu Daud menjadi rajanya di tengahtengah mereka. Aku TUHAN yang mengatakannya (ay. 24).

Sebutan gembala pada raja secara tradisi bukanlah suatu yang baru di kalangan Israel, karena hal ini sudah familier dipakai di Timur Tengah. Perbedaannya adalah, karena istilah gembala dikenakan pada Messias sebagai keturunan dari Daud pada masa akan datang, pada hal kenyataannya Israel ada dalam pembuangan. Penekanan pada satu gembala dalam ayat ini disebabkan pemisahan di masa lalu, di mana setiap bagian Israel mempunyai gembala sendirisendiri. Pada situasi ini sudah berakhir, dan untuk selanjutnya Israel hanya akan memiliki seorang gembala saja. ${ }^{28}$ Situasi gembala yang diwakili juga jelas, gembala ilahi akan mengumpulkan kawanan yang terserak dan mengembalikan ke Palestina, sedangkan gembala dunia akan memelihara mereka setelah pulang ke tanah yang dijanjikan. ${ }^{29}$

Jadi gembala atau raja baru ini akan berperan secara aktif dengan mendapatkan otoritas dari Allah setelah Israel kembali dan terjadi restorasi langsung dari Allah. Daud yang dimaksud adalah seorang dari keturunan Daud, dan bukan Daud sendiri.

Yehezkiel 37:24-25, penglihatan berkaitan dengan tulang-tulang kering yang dibangkitkan. Diawali dengan suatu dialog antara Yehezkiel dengan penglihatan tulang-tulang kering akhirnya muncul ayat 24-25 tersebut. Dengan nubuat ini Yehezkiel meyakinkan Israel bahwa TUHAN mampu mengembalikan Israel yang sudah berserakan diberbagai tempat kembali ke tanah perjanjian Palestina. Secara khusus ayat 24-25 ini yang mengungkapkan tentang Mesias. Yehezkiel melihat teokrasi dari sisi yang lain, bukan hanya sistem politik dan

\footnotetext{
${ }^{25}$ G.R. Beasley Murry, Tafsiran Alkitab Nasa Kini 2 (jakarta:Yayasan Komunikasi Bina Kasih, 1976), 524.

${ }^{26}$ Ibid.

${ }^{27}$ M.S. Siahaan, Pengaharaan Mesias, 55.

${ }^{28}$ Kaiser, Teologi. 305.

${ }^{29}$ Ibid.
} 
pemerintahan saja. ${ }^{30}$ Raja tersebut tidak bertanggung jawab atas kebangkitan kembali Israel baru, karena hal tersebut tanggung jawab dari pada TUHAN secara langsung. Tugas utama raja baru atau Mesias ini adalah menyatukan semua suku Israel menjadi satu di bawah kekuasaannya.

\section{Nabi Daniel}

Nubuatan Daniel berkaitan dengan Mesias adalah dalam pasal-pasal 2:34-35; 7:13; dan 9:24-25. Daniel hidup dalam pembuangan telah mendapat penglihatan-penglihatan yang brhubungan dengan kedatangan Mesias.

Daniel 2:34-35, mengungkapkan batu yang terungkit lepas tanpa perbuatan tangan manusia dan meremukkan patung tersebut adalah Mesias yang akan mendirikan kerajaanNya di muka bumi, yang kebesarannya melebihi kebesaran kerajaan yang termasyur yang pernah muncul sebelumnya di muka bumi. ${ }^{31}$ Tekanan dalam nubuatan di sini adalah Mesias dan kebesaran kerajaannya yang melebihi kebesaran kerajaan di bumi.

Daniel 7:13-14, terdapat nubuatan tentang kedatangan "Anak Manusia" yang menunjuk pada Mesias (Kristus) dalam kedatangannya yang kedua. Memang dalam nubuatan ini tidak menyebutkan tentang "seorang Raja" namun ada kerajaan-kerajaan yang diungkapkan. Secara konteknya nubuatan tersebut berkaitan dengan kondisi zaman pada waktu-waktu akhir, di mana keraajaan-kerajaan dunia yang lalim akan dilenyapkan dan kerajaan Allah sendiri akan dinyatakan. ${ }^{32}$ Kerajaan Allah tersebut dipimpin oleh anak manusia atas mandat dari "Yang Lanjut Usianya.

Seorang seperti "Anak manusia" yang diungkapkan (ay. 13) belum pasti berarti pribadi tertentu, mungkin juga sifat kemanusiaan itulah yang hendak ditekankan. Bertentangan dengan raja-raja dunia yang lalim, maka penguasa yang baru tersebut memiliki sifat sebagai "anak manusia, kemanusiaan." Kedua-duanya (penguasa lama dan baru) berwujud makhluk dan pemerintah dunia, tetapi kelaliman di satu pihak, yang bertentangan dengan perikemanusiaan dipihak yang lain. Dalam nubuatan ini, Allah sendiri akan mendatangkan penguasa yang baru itu (Mesias): seluruh kekuasaan di bumi akan diserahkan kepada "orang-orang kudus milik Yang Mahatinggi (Dan. 7:18, 22, 27). ${ }^{33}$

Daniel 9:24-27, membicarakan tentang waktu yang ditentukan oleh Allah bagi bangsa Israel untuk pemuliaan dan datangnya seorang raja, yaitu Mesias yang akan membinasakan musuh-musuhnya. ${ }^{34}$ Nubuat ini tidak hanya berbicara tentang bangsa Israel yang berakhir pada kedatangan Mesias yang kedua kalinya saja, tetapi juga mengungkapkan tentang Israel di masa akhir, yaitu saat kedatangan Kristus yang kedua kalinya. Orang Israel akan membentuk negara tersendiri di tanah airnya setelah mereka tersebar di penjuru dunia, dan gerakan dunia menuju pemerintahan global juga sedang berlangsung. Muncul juga gerakan yang mengarah kepada

${ }^{30}$ M.S. Siahaan, Pengaharaan Mesias, 68.

${ }^{31}$ John F. Walvoord, Penggenapan Nubuat Masa Kini-Zaman Akhir, terj: tn (Malang: Gandum Mas, 2004). 278.

${ }^{32}$ D.C. Mulder, Pembimbing ke dalam Perjanjian Lama (Jakarta: BPK Gunung Mulia, 1963). 234.

${ }^{33}$ Bart, Theologia 2. 181.

${ }^{34}$ Walvoord, Penggenapan Nubuat. 295-330. 
agama dan penyembahan global. Suasana damai dan berhenti dari peperangan, pertobatan sejati dengan mengakhiri dosa, keadilan dan kedamaian diungkapkan dalam nubuatan ini. ${ }^{35}$

\section{Nabi Hosea}

Nubuatan Hosea tentang Mesias terdapat pada Hosea 3:1-5, khususnya ayat 4-5. Bagian pertama nubuat ini (ay. 4) sudah tergenapi ketika Asyur menjadikan Israel sebagai tawanan (722 s.M) sehingga keadaan masyarakat Israel menjadi berserakan di pembuangan dan mereka tidak memiliki raja. Namun ayat 5, belum tergenapi karena berbicara tentang hari akhir, yang menunjuk pada pemulihan takhta Daud, dan hal ini tergenapi dengan kedatangan Mesias. ${ }^{36}$ Yehuda akan dibawah pemerintahan seorang raja ilahi dari keturunan Daud, yaitu Mesias. Ia akan memerintah sehingga setiap lutut bertelut dan setiap lidah mengaku bahwa Ia adalah Tuhan $^{37}$.

\section{Nabi Amos}

Bagianyang berkaitan dengan Mesias dalam kitab Amos adalah pasal 9:11-15. Permusuhan yang mendarah daging dari Edom mengarah ke pemandangan eskatologis dengan kedatangan tokoh dari Tuhan yang akan merobohkan Edom, dan tokoh tersebut dari dinasti Daud, yaitu Mesias. Edom merupakan salah satu tanda yang mencuat akan kehadiran kerajaan Mesianis. ${ }^{38}$ Amos menutup nubuatnya dengan mencatat kenikmatan kemakmuran yang terjamin (13-15), kemakmuran yang begitu melimpah ruah, dari musim ke musim berikutnya. Tanah Israel akan menjadi berproduktifitas tinggi, dan kemakmuran itu dinikmati oleh orang-orang yang tinggal di dalamnya untuk waktu yang lama. ${ }^{39}$ Suatu pemandangan sangat mengagumkan di mana Mesias berkuasa di Israel ini sebagai penggenapan perjanjian yang telah dibuat oleh Allah kepada umat pilihanNya, Israel.

\section{Nabi Mikha}

Pengharapan akan kedatangan Mesias oleh Mikha diungkapkan dalam pasal 5:1-4a. Berlawanan dengan raja Israel yang dikalahkan ini, akan timbul seorang raja baru yang akan

\footnotetext{
${ }^{35}$ Ibid. 331.

${ }^{36}$ Chr. Barth, Theologia Perjanjian Lama 2 (Jakarta: BPK Gunung Mulia, 1989). 166.

${ }^{37}$ J.B. Hinley, Tafsiran Masa Kini, terj: Naipopos (Jakarta: Yayasan Komunikasi Bina Kasih, 1976). 579.

${ }^{38}$ J.A. Motyer, Tafsiran Masa Kini, (Jakarta: Yayasan Komunikasi Bina Kasih, 1976). 642.

${ }^{39}$ Ibid.
} 
memerintah Israel (ay. 1), dan ia akan lahir di suatu kota yang hampir tak layak diperhitungkan di tengah-tengah kota-kota Yehuda, yaitu Betlehem. Diungkapkan tentang waktu permulaan dari raja yang baru, yaitu sejak purbakala, yang berarti nenek moyang dari Mesias ini sudah ada sejak kekekalan masa lampau sudah ada. ${ }^{40}$

Penafsiran nubuatan ini seyogyanya dimulai dari ungkapan "ia membiarkan mereka " (ay. 2). Penafsirannya dapat dibandingkan dengan Mikha 4, di mana Tuhan semestinya menyerahkan umatNya ke tangan musuh-musuhnya. Yerusalem menjadi reruntuhan, raja dengan semua penasehatnya menghilang, rakyat dipaksa untuk digiring ke Babel, putri Sion disergap kesakitan seperti perempuan yang melahirkan (Mi. 4:9-10, 14). Krisis yang mengerikan ini akan berakhir, bila perempuan yang akan melahirkan telah bersalin, dan saudaranya telah kembali kepada Israel, artinya telah pulang dari pembuangan (Mi. 5:3). Berkaitan dengan penyelamatan Sion tersebut, maka kerajaan yang berpusat di kota itu pun akan dipulihkan kembali (Mi. 4:6-8). Rajanya akan dibangkitkan oleh Tuhan sendiri yang tidak lain adalah dari Betlehem, tempat asal Daud. Permulaan raja yang dibangkitkan Tuhan tersebut sudah ada jauh di masa lampau atau sejak purbakala. ${ }^{41}$

Pemikiran nabi Mikha tentang Mesias terkandung ide bahwa raja yang akan datang tersebut sudah ada sejaak sebelum dunia dijadikan (kekekalan masa lampau), dan hal ini adalah menunjuk pada eksistensi Mesias itu sendiri adalah Allah. Selain ia sebagai penguasa, Mikha mengungkapkan bahwa ia juga sebagai gembala bagi Israel. Mesias ini seorang keturunan Daud, yang memiliki kekuasaan yang tidak terbatas, dengan suasana damai sejahtera.

\section{Nabi Zakaria}

Zakaria adalah nabi yang bekerja setelah pemulangan dari pembuangan. Kerajaan Israel tidak terpecah menjadi dua kerajaan, melainkan sudah menjadi satu kerajaan, yaitu Israel. Proses perkembangan dalam penantian Mesias ini dapat dilihat dalam pasal 9:9-10.

Nubuat ini cukup menonjol dengan dilatarbelakangi seorang raja pada saat masuk Yerusalem, sesudah mendapat kemenangan yang gemilang, penuh dengan nyanyian syukur karena kemenangan raja. Sifat raja tersebut adalah "adil dan jaya", namun dibalik sifat tersebut ada sifat lemah lembut dari Sang Raja, yaitu memakai kendaraan orang kecil, keledai. Ia menolak dan melenyapkan peralatan perang, dan bahkan memberitakan damai (syalom) bagi bangsa-bangsa. Nubuat ini nampak berbeda dengan nubuat yang disampaikan oleh nabi-nabi yang terdahulu. Walaupun Raja Adil dan Damai itu seorang raja yang kuat, tetapi kekuatannya itu bukan dengan keperkasaan dan tangan besi, melainkan dengan Roh Tuhan (Za. 4:6). Suasana yang baru itu sangat besar pengaruhnya dalam penantian dan pemberitaan raja yang akan datang. Penampilan raja yang adil dan jaya dengan kendaraan keledai merupakan penggambaran penampilan yang sangat sederhana seperti seorang hamba yang dilukiskan oleh Yesaya $53 .{ }^{42}$

\footnotetext{
${ }^{40}$ Gleason L. Archer, Tafsiran Masa Kini (Jakarta: Yayasan Komunikasi Bina Kasih, 1976). 673-674.

${ }^{41}$ Barth. Theologia 2. 168.

${ }^{42}$ A. Seventer, Tafsiran Alkitab, Zakharia dan Hagai (Jakarta: BPK Gunung Mulia, 1983). 54-55.
} 


\section{Kegenapan Penggenapan Nubuat Mesias Masa Intertestament}

Jikalau disimpulkan nubuatan tentang Mesias yang disampaikan oleh para nabi Israel, bahwa Mesias itu secara biologis adalah keturunan Daud, dan Dia akan mengokohkan kerajaan Daud yang telah runtuh. Ia diurapi oleh Allah dengan penyertaan Roh Allah secara menakjubkan untuk membebaskan membebaskan umatNya dari penderitaan penindasan dari bangsa-bangsa lain. Dia akan memerintah dengan penuh damai tentram, keadilan, dan masyarakatnya hidup dalam kelimpahan untuk selama-lamanya. Sifat kerendahan hati ditonjolkan dalam kehidupannya, walaupun Dia seorang yang perkasa.

Namun di masa inter testament terjadi pergeseren pemikiran di masa itu, lebih menekankan pembebasan Sang Mesias bagi bangsa Israel yang tertindas dan mengalami penderitaan yang sangat berkepanjangan. Gagasan tentang Mesias tidak lagi berfokus pada nubuatan nabi-nabi tetapi lebih mengarah pada kitab-kitab apokripha yang tidak diwahyukan oleh Allah. Sebagai contoh dalam Mazmur Salomo, orang Yahudi berdoa untuk Kerajaan Allah (17:4), melalui raja yang dijanjikan, yaitu Anak Daud (17:5, 23), raja ini akan menjadi raja yang diurapi oleh Tuhan (17:6). Bila Ia bangkit, akan menghajar bumi dengan muluutNya, akan membersihkan dunia dari dosa, akan menghacurkan bangsa-bangsa kafir dan membebaskan Yerusalem, dan Ia akan memerintah orang Yahudi untuk selama-lamanya. Itulah pernyataan doa orang Yahudi. Kerajaan yang mereka inginkan ini adalah bersifat duniawi dengan politik dan keagamaan yang kuat. $^{43}$

Dari dukumen masyarakat Qumran, mereka mengharapkan imam dan raja yang diurapi. Keimaman Mesias ini lebih tinggi dibandingkan dengan kerajaan Mesias. Dalam perumpamaan Henokh, meyakini bahwa Anak Manusia yang ada sebelum dunia dijadikan, dikemudian hari akan mendirikan kerajaan di bumi. Anak Manusia ini disebut Mesias. Dalam kitab Apokalipsis, Mesias ini akan memerintah dunia akan datang; Ia akan dipelihara oleh Yang Mahatinggi; Ia akan menempatkan orang-orang berdosa di hadapan kursi pengadilanNya. Dalam kitab Barukh, Mesias akan memerintah dalam kerajaan mesianik. ${ }^{44}$

Masih banyak lagi pendapat lain berkaitan dengan Mesias ini dalam pandangan orang Yahudi di masa antara Perjanjian Lama dan perjanjian Baru. Itulah sebabnya banyak orang Yahudi yang tidak mau percaya bahwa Yesus Kristus dari Nazaret itu adalah Mesias. Hal ini terjadi karena mereka berpikir bahwa Mesias itu seorang pembebas secara revolosioner, berperang melawan musuh dengan kekuatan bala tentera dari sorga untuk memerangi penindaspenindas Israel. Mesias menjadi raja, pemimpin besar yang perkasa. Apalagi ketika mereka menyaksikan kematian Yesus Kristus di kayu salib sebagai orang terkutuk, mereka menjadi antipati akan ke Mesiasan Yesus. Itulah sebabnya Yahudi ortodok hingga kini masih menunggu kedatangan Mesias yang dijanjikan sebagai pembebas dan raja itu.

\footnotetext{
${ }^{43}$ George Eldon Ladd, Teologi Perjanjian Baru I, terj: Urbanus Selan (Bandung: Kalam Hidup, 2002).
}

181.

\footnotetext{
${ }^{44}$ Ibid. 182.
} 


\section{Bibliografi}

Archer, Gleason L, Tafsiran Masa Kini. Jakarta: Yayasan Komunikasi Bina Kasih, 1976.

Berkhof , Louis, Teologi Sistematik 3, Doktrin Kristus, terjemahan:Yudha Thianto, Surabaya: Penerbit Momentum, 2008.

Barth, Chr, Theologia Perjanjian Lama 1. Jakarta: BPK Gunung Mulia, 1989.

Barth, C. Theologia Perjanjian Lama 2. Jakarta: BPK Gunung Mulia, 1989.

Cawley, F, Millard, A.R. Tafsiran Alkitab Masa Kini 2. Jakarta: BPK Gunung Mulia, 1985).

Douglas, J. D. \& Tenney, Merrill C. The New International Dictionary Of The Bible. Michigan: Zondevan Publishing House, 1987.

Groenen ,C. Pengantar ke Dalam Perjanjian Lama . Yogyakarta: Kanisius, 1992.

Guthrie, Donald, Teologi Perjanjian Baru 1. Jakarta: BPK Gunung Mulia, 2011.

Hinley, J.B. Tafsiran Masa Kini, terj: Naipopos. Jakarta: Yayasan Komunikasi Bina Kasih, 1976.

Kidner, Derek. Tafsiran Alkitab Masa Kini 2, terj:W.B. Sijabat. Jakarta: BPK Gunung Mulia, 1985.

Ladd,George Eldon. Teologi Perjanjian Baru 1, Bandung: Yayasan kalam Hidup, 2002.

Mulder, D.C. Pembimbing ke dalam Perjanjian Lama. Jakarta: BPK Gunung Mulia, 1963.

Motyer, J.A. Tafsiran Masa Kini, Jakarta: Yayasan Komunikasi Bina Kasih, 1976.

Murry, G.R. Beasley. Tafsiran Alkitab Nasa Kini 2. Jakarta:Yayasan Komunikasi Bina Kasih, 1976.

Siahaan,M.S. Pengaharaan Mesias dalam Perjanjian Lama,BPK: Gunung Mulia, 1990.

Seventer, A. Tafsiran Alkitab, Zakharia dan Hagai. Jakarta: BPK Gunung Mulia, 1983.

VanGemeren,Willem A. Penginterpretasian Kitab Para Nabi . Surabaya: Momentum, 2011.

Widyapranawa, S.H. Tafsiran Alkitab, Kitab Yesaya. Jakarta: BPK Gunung Mulia, tt.

Walvoord, John F. Zuck, Roy B. (ed), The Bible Knoledge Commentary.Colorado: Chariot Victory Publishing, tt.

Walvoord, John F.Penggenapan Nubuat Masa Kini-Zaman Akhir, terj: tn. Malang: Gandum Mas, 2004. 